\section{Influence of Mammalian Growth Hormone on Rate of Growth of Fish}

The influence of purified mammalian growth hormone on laboratory animals is well known. Pickford and Thompson ${ }^{1}$ have shown that it can influence the growth-rate of the marine teleost Fundulus heteroditus. At the suggestion of Prof. F. G. Young, the influence of the hormone on hatcheryreared brown trout (Salmo trutta) has been investigated.

Batches of ten four-year old fish were used for the work. The experimental fish were injected, intra peritoneally, twice a week with hormone solution, each fish receiving $100 \mu \mathrm{gm}$. hormone/10-gm. fish/ week. A control batch of fish kept with the experimental fish were similarly injected with 0.6 per cent saline. A third batch of fish kept in a separate pond were unhandled throughout the experiment. All the fish were fed to capacity with a mixture of liver and 'Dog-e-tox' dog-food.

Over a four-week period in March, a significant increase in specific growth-rate, expressed as percentage length per week $\frac{\ln L_{\mathrm{II}}-\ln L_{\mathrm{I}}}{T_{2}-T_{1}} \times 100$, of the experimental fish over the controls was obtained. Experimental fish : Mean 0.7 per cent ; stand. error of mean 0.06
Control fish : Unhandled fish (8 flsh) : ", 0.2 " " " " " " " " 0.05

The experiment was repeated over four weeks in July using other fish, and a similar result was obtained.

Experimental fish : Unhandled fish

Mean 1.1 per cent ; stand. error of mean 0.09 " 1.4 " " " " " " " " " 0.17

The adverse effect of handling on the growth-rate of the fish is well illustrated by the July results, when the unhandled fish grew at a much greater rate than did the controls.

Owing to the difficulty of accurately assessing the food intedke of fish kept under hatchery conditions, it is impossible to determine whether or not the low growth-rate of the unhandled fish in March is a reflexion of a seasonal variation in the rate of secretion of an endogenous growth hormone. It is hoped to elucidate this point in further work.

Freshwater Biological Association,

$$
\text { D. R. SwrFT }
$$
Ferry House,

Ambleside, Westmorland. Feb. 15 .

${ }^{2}$ Pickford, G. E., and Thompson, E. F., J. Exp. Zool., 109, 367 (1948).

\section{Effect of Mercury Vapour on the Active Uptake of Sucrose by Leaf Tissues}

ALTHOUGH the poisonous action of mercury vapour on plants was noticed as far back as $1797^{1}$, little attention has been paid to this compared with the action of mercury compounds. In 1934, Zimmerman and Crocker $^{2}$, investigating the damage done to roses by mercuric chloride applied to the soil, found that the effect was due to the formation of free mercury in the soil, the vapour of which attacked the shoot. In the course of studying the uptake of sucrose by floating leaf disks of Atropa belladonna (deadly
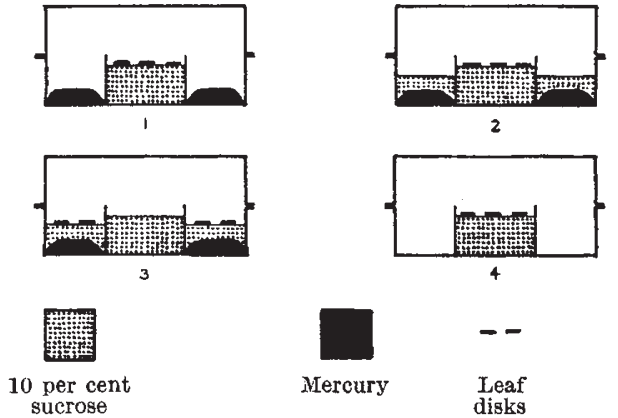

10 per cent sucrose

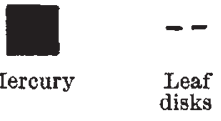

Fig. 1. Treatments used in the investigation of the effect of metallic mercury on the active uptake of sucrose by the leaf tissue
of Atropa belladonna

nightshade) and Lactuca sativa var. capitata (lettuce), we have found that the active uptake is greatly reduced by the presence of free mercury.

The leaf disks were floated at $25^{\circ} \mathrm{C}$. for $9 \mathrm{hr}$. on 10 per cent sucrose solution in Petri dishes placed inside closed vessels. Sucrose uptake, which was measured as increase in dry weight of the disks ${ }^{3}$, had already been found to be considerably less in nitrogen than in air ${ }^{4}$, and this difference was taken as a measure of the active uptake.

To investigate the effect of metallic mercury on active uptake, four treatments (illustrated in Fig. 1) were investigated : (1) mercury placed in the vessels around the Petri dishes; (2) mercury similarly placed but covered with sucrose solution; (3) disks floated on the sucrose solution covering the mercury ; (4) no mercury present.

The surface area of mercury was the same in treatments (1)-(3). The uptake in nitrogen, which was found to be unaffected by these treatments, was subtracted from the results to give the active uptake in each case.

Each of these four treatments was performed in both light and dark, the experiments being conducted under fluorescent light with the vessels of the dark series made light-proof with paint. The experiment was replicated once and carried out on four occasions, so that a combined analysis of variance of the four experiments was possible. The results are shown in Table $\mathrm{I}$.

Table 1. ACtive Uptake of Sucrost (in mam.) of Floating Leaf DISKS OF Atropa belladonna TREATED AS IN FIG. 1

\begin{tabular}{|c|c|c|c|c|c|}
\hline & \multicolumn{4}{|c|}{ Treatment } & \multirow{2}{*}{ Mean } \\
\hline & 1 & $2^{x+1}$ & 3 & 4 & \\
\hline $\begin{array}{l}\text { Light } \\
\text { Dark }\end{array}$ & $\begin{array}{l}0.63 \\
0.38\end{array}$ & $\begin{array}{l}6 \cdot 90 \\
4 \cdot 65\end{array}$ & $\begin{array}{l}6 \cdot 30 \\
4 \cdot 48\end{array}$ & $\begin{array}{l}6 \cdot 13 \\
5 \cdot 60\end{array}$ & $\begin{array}{l}4 \cdot 99 \\
3 \cdot 77\end{array}$ \\
\hline Mean & $0 \cdot 50$ & $5 \cdot 77$ & $5 \cdot 39$ & $5 \cdot 86$ & \\
\hline \multicolumn{6}{|c|}{$\begin{array}{l}\text { Least significant } \\
\text { differences } \\
(P=0.05)\end{array}\left\{\begin{array}{l}\text { between means of light and dark treat- } \\
\text { ments }=1.00 \\
\text { between means of treatments } 1 \text { to } 4=1.42\end{array}\right.$} \\
\hline
\end{tabular}

A free surface of mercury almost completely eliminated active uptake of sugar $(P=0.01)$, whereas if the mercury were covered by solution it had no inhibitory effect even when the tissue was floated on the covering solution. The effect, therefore, seemed to be due to the mercury vapour in the air over the disks. Uptake in light was greater than in the dark $(P=0.05)$, but light had no significant effect on the response to mercury vapour. The effects 